\title{
Factorial Design Evaluation of Oil Removal from Fibrous Sorbents by Biosurfactant
}

\author{
Q.F. Wei ${ }^{1}$, F.L. Huang' ${ }^{1}$, R.R. Mather ${ }^{2}$, A.F. Fotheringham² \\ 1 Key Laboratory of Eco-textiles, Ministry of Education, Southern Yangtze University, Wuxi 214122 - China \\ 2 Heriot-Watt University, Galashiels TD1 3HF - United Kingdom \\ e-mail: qfwei@sytu.edu.cn -windhuang325@163.com -r.r.mather@hw.ac.uk - a.f.fotheringham@hw.ac.uk
}

\begin{abstract}
Résumé - Évaluation par analyse factorielle de l'élimination de pétrole sur des adsorbants fibreux par des biotensioactifs - L'objectif de ce travail est d'une part d'examiner l'efficacité des biotensioactifs pour l'élimination de pétrole sur des adsorbants non tissés de polypropylène usagés, et d'autre part d'étudier l'effet de paramètres fondamentaux tels que le type d'adsorbant, le temps de lavage, la dose de tensioactif et la température. Les biotensioactifs sont biodégradables et peuvent également accroître la biodégradation du pétrole par augmentation de la biodisponibilité des composés hydrophobes. On a utilisé l'analyse factorielle pour examiner l'élimination de pétrole par biotensioactif sur des adsorbants usagés. L'étude montre que la taille des pores, la concentration du biotensioactif, la température et le temps de lavage ont des effets différents selon le type de pétrole. Dans le cas de pétrole brut et de pétrole vieilli à $25 \%$ (perte de poids par évaporation), la taille des pores et le temps de lavage sont les facteurs significatifs qui influent sur l'élimination du pétrole. Dans le cas de pétrole vieilli à $50 \%$, la température apparaît comme le facteur le plus significatif. On démontre que le lavage par biotensioactif présente un potentiel important pour le recyclage des adsorbants usagés.
\end{abstract}

\begin{abstract}
Factorial Design Evaluation of Oil Removal from Fibrous Sorbents by Biosurfactant The objective of this study was to test the feasibility of biosurfactant for the removal of oil from used polypropylene nonwoven sorbents and to investigate the effect of basic parameters such as sorbent type, washing time, surfactant dosage and temperature. Biosurfactants are biodegradable and can also enhance the biodegradation of oil by increasing the bioavailability of hydrophobic compounds. Factorial design was employed to examine the oil removal from used sorbents by biosurfactant. The study revealed that pore size, biosurfactant concentration, temperature and washing time exhibit different effects on oil removal for different types of oil. For crude oil and 25\% weathered (weight loss from crude oil by evaporation), pore size and washing time are significant factors influencing oil removal from used sorbents. For 50\% weathered oil, temperature appears to be most significant factor influencing oil removal. It has been shown that biosurfactant washing has considerable potential for recycling used oil sorbents.
\end{abstract}




\section{INTRODUCTION}

There has been increasing demand for oil supply in the modern industrial world. Oil spills can be caused by operation failures, equipment breaking down, accidents, natural disasters during the production, transportation, storage and use of oil. Oil spills into land, river or ocean impose a major problem on the environment (Wiens, 1996). A lot of effort has been made to combat oil spills and various processes have also been developed to remove oil from contaminated areas. Among them mechanical recovery of oil by porous sorbents has been recognized as one of the most promising countermeasures. Oil sorbents are used to capture and retain oil for retrieval in oil spill recovery. Nonwoven materials are the most commonly used oil sorbents in oil spill recovery (Teas et al., 2001). The porous structures of nonwoven oil sorbents help oil transport from spilled areas to sorbents. Once this sorption is achieved, oil sorbents can then be removed for further treatment. However, in this process most of the used oil sorbents end up in landfills and incineration, which either produces another source of pollution or increases the oil recovery cost. There is an increased interest in promoting environmental responsibility through cleaning and reusing products that have traditionally been discarded after a single use (Peaslee and Roberts, 1997). Washing with surfactants is common practice in cleaning fibrous materials (Azemar et al., 1993).

A surfactant is briefly defined as a material that can greatly reduce the surface tension of water when used in very low concentrations. A particular type of molecular structure performs as a surfactant is made up of a water soluble (hydrophilic) head and a long water insoluble (hydrophobic) tail. Surfactants are usually made from petrochemicals, often termed "synthetic" materials. Almost all the products used for laundering, household cleaning and industrial cleaning are surfactant-based $(\mathrm{Fu}$ and Matthews, 1999). In recent years, biological surface-active compounds, biosurfactants, are gaining prominence and have already taken over in a number of important industrial uses, due to their advantages of biodegradability, production of renewable resources and functionality under different conditions (Dyke et al., 1991).

Biosurfactants are biodegradable and can also enhance the biodegradation of oil by increasing the bioavailability of hydrophobic compounds (Ron and Rosenberg, 2002). The objective of this study was to test the feasibility of biosurfactants for the removal of oil from used polypropylene nonwoven sorbents and to investigate the effect of basic parameters such as sorbent type, washing time, surfactant dosage and temperature. If this study can prove the use of biosurfactants for cleaning used oil sorbents, there is great potential to recycling used oil sorbents and reducing environmental pollutions. Since there were different factors involved in this process, factorial design was used in the study to examine oil removal from used sorbents by biosurfactants in order to improve the experimental efficiency. In a factorial design several factors are varied simultaneously according to a special experimental layout - a factorial design. There are several advantages to factorial design compared with the more traditional one-factor-at-a-time approach (Winer et al., 1991).

\section{MATERIALS AND METHODS}

\subsection{Preparation of Test Oils}

The crude oil was obtained from the North Sea and the weathered oils were prepared by heating the crude oil on a hot plate at $40^{\circ} \mathrm{C}$. The weathered oils were made with $25 \%$ and $50 \%$ weight loss respectively. The oil density and viscosity were measured using a digital density meter and dynamic viscosity meter respectively. The measurements were run in triplicate and the mean values are reported in Table 1.

TABLE 1

Crude oil and weathered oil properties

\begin{tabular}{l|c|c|c}
\hline Oil Type & Crude & $25 \%$ weathered & $50 \%$ weathered \\
\hline Density $\left(\mathrm{g} / \mathrm{cm}^{3}\right)$ at $20^{\circ} \mathrm{C}$ & 0.814 & 0.849 & 0.890 \\
\hline $\begin{array}{l}\text { Viscosity }(\mathrm{cP}) \text { at } 20^{\circ} \mathrm{C} \\
\left.\text { (shear rate } 10.82 \mathrm{~s}^{-1}\right)\end{array}$ & 18.7 & 54.8 & 631 \\
\hline
\end{tabular}

\subsection{Sorbent Materials}

The materials chosen were typical polypropylene nonwoven oil sorbents with different pore sizes. characterised based on BS EN 29073 (Methods of Tests for Nonwovens). Samples were cut to the size of $120 \mathrm{~mm} \times 50 \mathrm{~mm}$. The sorbents used in this study are listed in Table 2.

TABLE 2

Oil Sorbent Properties

\begin{tabular}{|c|c|c|c|}
\hline \multicolumn{2}{|l|}{ Sorbent } & SB1 & SB2 \\
\hline \multicolumn{2}{|l|}{ Processing } & Nonwoven & Nonwoven \\
\hline \multicolumn{2}{|l|}{ Material } & Polypropylene & Polypropylene \\
\hline Mass & $\left(\mathrm{g} / \mathrm{m}^{2}\right)$ & 250 & 300 \\
\hline Thickness & $(\mathrm{mm})$ & 5.00 & 3.60 \\
\hline Average $\mathrm{pc}$ & $(\mu \mathrm{m})$ & 311 & 163 \\
\hline
\end{tabular}

Oil content in sorbent was calculated as the ratio of oil adsorbed to dry sorbent mass:

Oil content $=\left(S_{t}-S_{o}\right) / S_{o}$

where: $S_{o}$ is the dry sorbent mass $(\mathrm{g})$ and $S_{t}$ is the total mass of oil adsorbed samples (g). 
TABLE 3

Factors and levels

\begin{tabular}{c|l|c|c|c|c|c|c}
\hline Factor & Description & \multicolumn{2}{|c|}{ crude oil } & \multicolumn{2}{c|}{ 25\% weathered } & \multicolumn{2}{c}{$50 \%$ weathered } \\
\hline & & Level 1 (L1) & Level 2 (L2) & Level 1 (L1) & Level 2 (L2) & Level 1 (L1) & Level 2 (L2) \\
\hline A & Pore size $(\mu \mathrm{m})$ & 163 & 311 & 163 & 311 & 163 & 311 \\
\hline B & Biosurfactant concentration $\left(\mathrm{cm}^{3} / \mathrm{dm}^{3}\right)$ & 10 & 20 & 10 & 20 & 10 & 20 \\
\hline C & Temperature $\left({ }^{\circ} \mathrm{C}\right)$ & 20 & 40 & 20 & 40 & 20 & 40 \\
\hline D & Washing time (minutes) & 15 & 30 & 30 & 60 & 60 & 120 \\
\hline
\end{tabular}

\subsection{Biosurfactant}

The biosurfactant used in this study was rhamnolipids biosurfactant JBR215 obtained from Jeneil Biosurfactant Company, USA. It is readily biodegradable and is an extracellular natural substance produced during precisely controlled fermentation processes utilising certain bacterial strains. JBR215 is an aqueous solution of rhamnolipids at $15 \%$ concentration. It is produced from sterilized and centrifuged fermentation broth. Two major rhamnolipids are present, in the chemical formulas of $\mathrm{C}_{26} \mathrm{H}_{48} \mathrm{O}_{9}, \mathrm{C}_{32} \mathrm{H}_{58} \mathrm{O}_{13}$.

\subsection{Factorial Design}

Before the factorial design, the trial tests were carried out. Based on results of trial tests, factors and level were chosen. The factorial design was made for the oil removal from the sorbents using the biosurfactant as indicated in Table 3 .

\subsection{Experimental Procedure}

$10 \mathrm{~cm}^{3}$ of the biosurfactant was added to a 2-litre beaker, which was placed a temperature adjustable heater. Deionised water was then added into the beaker to $500 \mathrm{~cm}^{3}$. The used sorbent with known oil content $(8 \mathrm{~g} / \mathrm{g})$ was placed in the solution and a wire mesh (openings $>1 \mathrm{~mm}$ ) was used to immerse the sorbent into the solution (about the middle position of the solution). After a certain length of time as listed in Table 3, more deionized water was added to allow the cell to overflow until all the floating oil had disappeared. The sorbent was then removed and transferred into a basin filled with clean deionised water $\left(1 \mathrm{dm}^{3}\right)$ and maintained for 10 minutes at $20^{\circ} \mathrm{C}$. The sorbent was rinsed again with $1 \mathrm{dm}^{3}$ clean deionised water for another 10 minutes at $20^{\circ} \mathrm{C}$. Oil remaining in each sorbent after washing was extracted by n-hexane and concentration was measured using the Perkin Elmer Lambda2 UV/Vis/NIR Spectroscopy. The measurements of concentration using absorption depend on a linear relationship between the concentration and the absorption, also known as Beer's law. For the UV/Vis spectroscopy, the quartz cells were used and concentrations in the $10^{-3}-10^{-2} \mathrm{~g} \cdot \mathrm{dm}^{-3}$ were used. Calibration curves relating to the concentrations of oils in $n$-hexane were prepared using the single wavelength of $223.7 \mathrm{~nm}, 224 \mathrm{~nm}$ and $294 \mathrm{~nm}$ for crude oil, $25 \%$ weathered oil and $50 \%$ weathered oil, respectively, because they are $\lambda_{\max }$ values.

\section{RESULTS AND DISCUSSION}

\subsection{Analysis of Main Effects}

Main effects plots were constructed to evaluate the significance of pore size, biosurfactant concentration, temperature and washing time on the efficiency of oil removal from used sorbents.

It is clear from the plots shown in Figure 1a that crude oil removal efficiency is mainly influenced by three factors: pore size, biosurfactant concentration and washing time. Temperature seems not to have significant effect. This is because temperature in the range between $20^{\circ} \mathrm{C}$ and $40^{\circ} \mathrm{C}$ does not significantly change the properties of oils and the biosurfactant. It can be seen that the effects of the three factors are in the same direction, indicating the same effect pattern. However pore size and washing time appear to have a more significant effect on the oil removal than biosurfactant concentration. Big pores in the sorbents facilitate the transport of the biosurfactant and movement of released crude oil from the sorbent. If the washing time is increased more biosurfactant will penetrated into the sorbent to removal the crude oil from the sorbents. Thus, it would be effective to increase the crude oil removal efficiency by just extending the washing time. Increase in the pore size of a sorbent can also lead to the increase in removal efficiency, but the increase in pore size can also cause the poor retention properties of a sorbent (Wei et al., 2003).

The main effect graph in Figure 1b clearly shows that pore size and washing time are highly significant for the $25 \%$ weathered oil removal. Big pores help the biosurfactant penetrate into the sorbent and the washing time enhances this penetration of the biosurfactant. Biosurfactant concentration and temperature appear to 

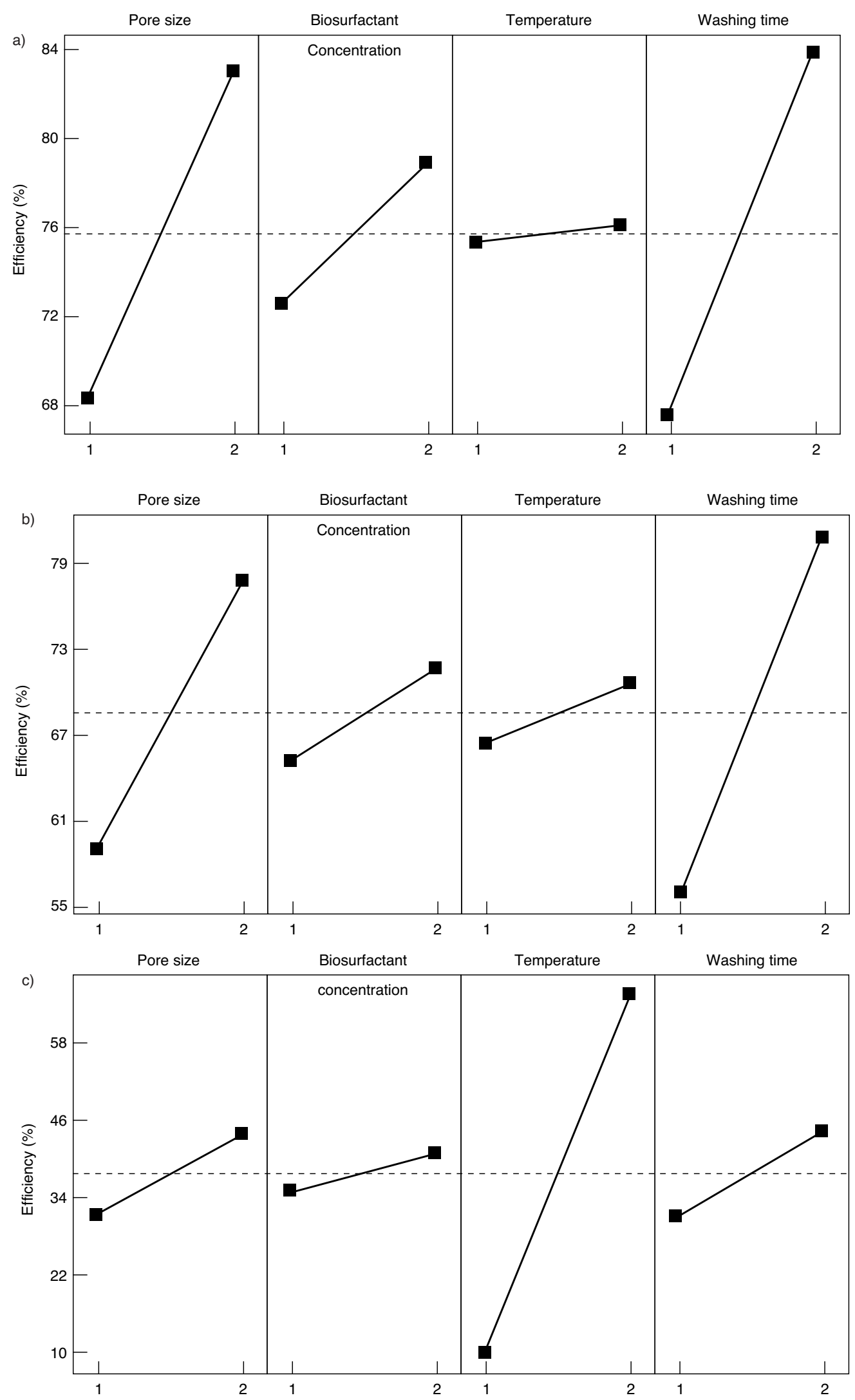

Figure 1

Main effects plot: (a) crude oil; (b) 25\% weathered oil; (c) 50\% weathered oil. 
exhibit some significance. The viscosity of the weather oil is more sensitive to the temperature change that of the crude oil. Therefore the temperature increase leads to the decrease in the viscosity of the $25 \%$ weathered oil, enhancing the mobility of the oil. All the factors tested show the same effect direction as indicated in Figure $1 \mathrm{~b}$. The increase in slope from lower level (1) to higher level (2) indicates a positive effect on the oil removal efficiency by the biosurfactant washing.

It is also clear from the main effects plot shown in Figure 1c that $50 \%$ weathered oil removal efficiency is significantly influenced by temperature. Temperature can significantly alter the viscosity of the $50 \%$ weathered oil. The viscosity of the $50 \%$ weathered oil drops over $35 \%$ as the temperature is increased from 20 Thus temperature increase leads to better oil removal from the sorbent. It can be seen that significance of the effects of the other three factors appears much smaller.

\subsection{Analysis of Interaction Effects}

Figure 2a illustrates the interaction of different factors on the crude oil removal. It can be seen that no interaction effects appear significant among the factors tested. The solid and dashed lines, each connecting two data points, representing low and high levels, respectively, are parallel or almost parallel. The $y$-axis of the plot shows the averages of the measured responses under the various combinations specified by the $x$-axis and the two lines. It is believed that effects of these factors are quite independent. The change in pore size, for instance, does not change the properties of biosurfactant.

The interaction of different factors on the removal of $25 \%$ weathered oil from used sorbents is shown in Figure $2 \mathrm{~b}$. It can be seen that the solid line appears to be parallel to the dashed line in every section. For example, in the section between temperature and washing time the oil removal efficiency is increased when washing time is increased from the lower level to the higher level at the lower temperature level, as indicated by the solid line in this section. At the higher temperature level, the oil removal efficiency is increased when washing time is increased from the lower level to the higher level as well, as indicated by the dashed line in this section, but the effect of temperature levels on oil removal efficiency by the different levels of washing time is not observed. Therefore there is no interaction between temperature and washing time. None of the interaction effects among the factors tested appears significant in other sections.

The interaction effects plot, illustrated in Figure 2c, indicates that none of the interaction effects is significant, among the factors tested for the $50 \%$ weathered oil. It can be seen that the effect lines in each section are nearly parallel.

\subsection{Analysis of Variance (ANOVA)}

Main effects plots can be used to analyse the significance of individual factor effects relative to each other, but whether a particular effect is statistically significant or not can be analysed by a main effects plot. Analysis of Variance (ANOVA) (Yang et al., 2001) allows the statistical significance of factor effects to be judged at a known level of risk.

Table 4 lists the factors and their significance on the oil removal from used, at a significance level of 0.05 $(\alpha=0.05)$. The table indicates that pore size, biosurfactant concentration, temperature and washing time exhibit different effects on oil removal for different types of oil. For crude oil and $25 \%$ weathered, pore size and washing time are significant factors influencing oil removal from used sorbents. It is expected that the efficiency of oil removal will be higher for crude oil and $25 \%$ weathered, if pore size and washing time are increased. Increasing pore size, however, will affect the retention properties of sorbents. Therefore extending washing time is a better option to increase removal efficiency. For $50 \%$ weathered oil, temperature appears to be most significant factor influencing oil removal. Thus, increasing washing temperature can be an option to improve oil removal efficiency.

TABLE 4

Factors and their effects on oil removal

\begin{tabular}{l|c|c|c|c}
\hline Type of oil & \multicolumn{4}{|c}{ Significance of factor at level, $\alpha=0.05$} \\
\hline & Pore size & $\begin{array}{c}\text { Biosurfactant } \\
\text { concentration }\end{array}$ & Temperature & Washing time \\
\hline Crude oil & Yes (H)* & Yes & No & Yes (H) \\
\hline $25 \%$ weathered oil & Yes (H) & Yes & Yes & Yes (H) \\
\hline $50 \%$ weathered oil & Yes & No & Yes (H) & Yes \\
\hline
\end{tabular}

* H in brackets indicates the higher level of significance.

\section{CONCLUSION}

It has been found that, with biosurfactant washing, more than $95 \%$ removal of the oil from sorbents was achieved depending on the washing conditions. It has been shown that biosurfactant washing has considerable potential for recycling used oil sorbents.

These laboratory-scale results indicate potential for biosurfactants in the recycling of used oil sorbent. Some other factors, such as stirring and $\mathrm{pH}$ value, however, may have to be considered in the application of biosurfactants on a field-scale. 
a)

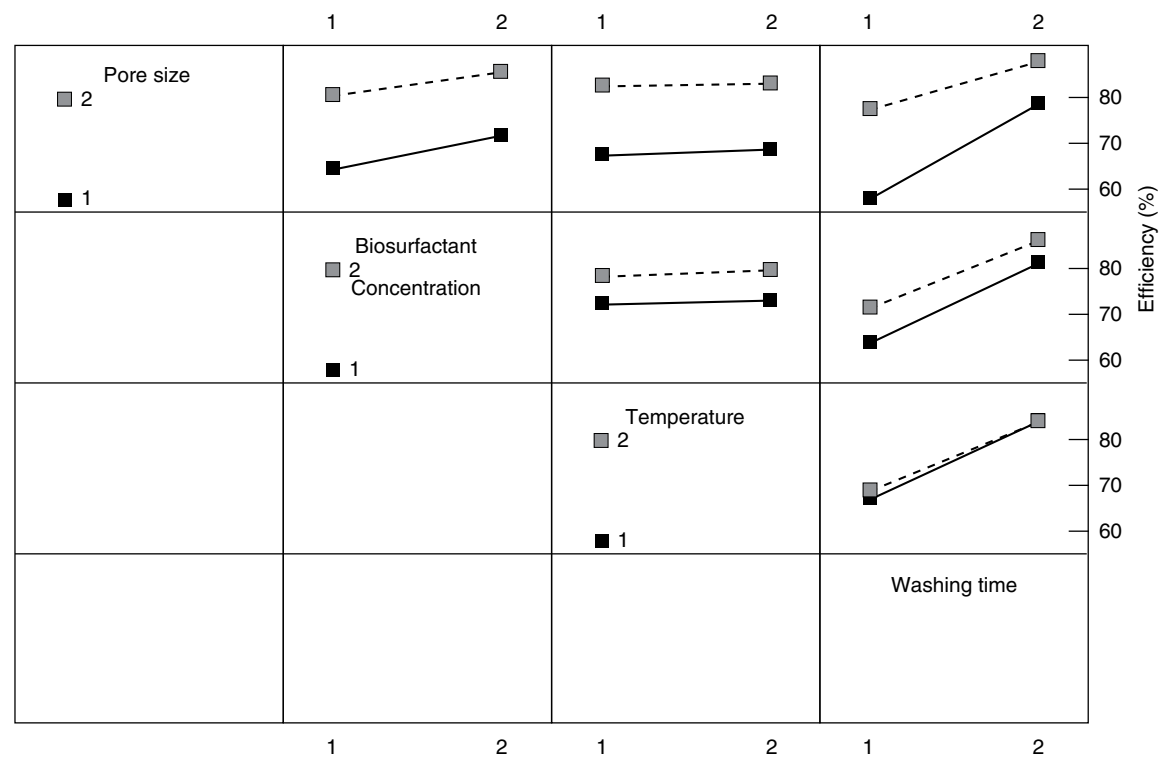

b)

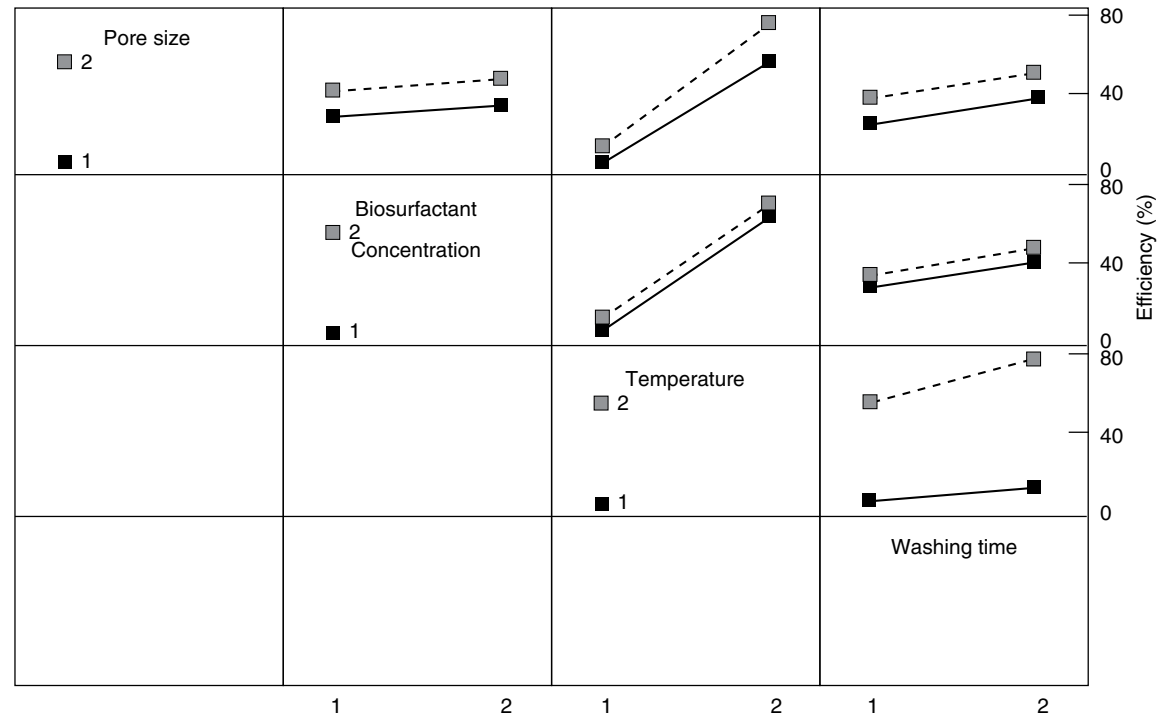

c)

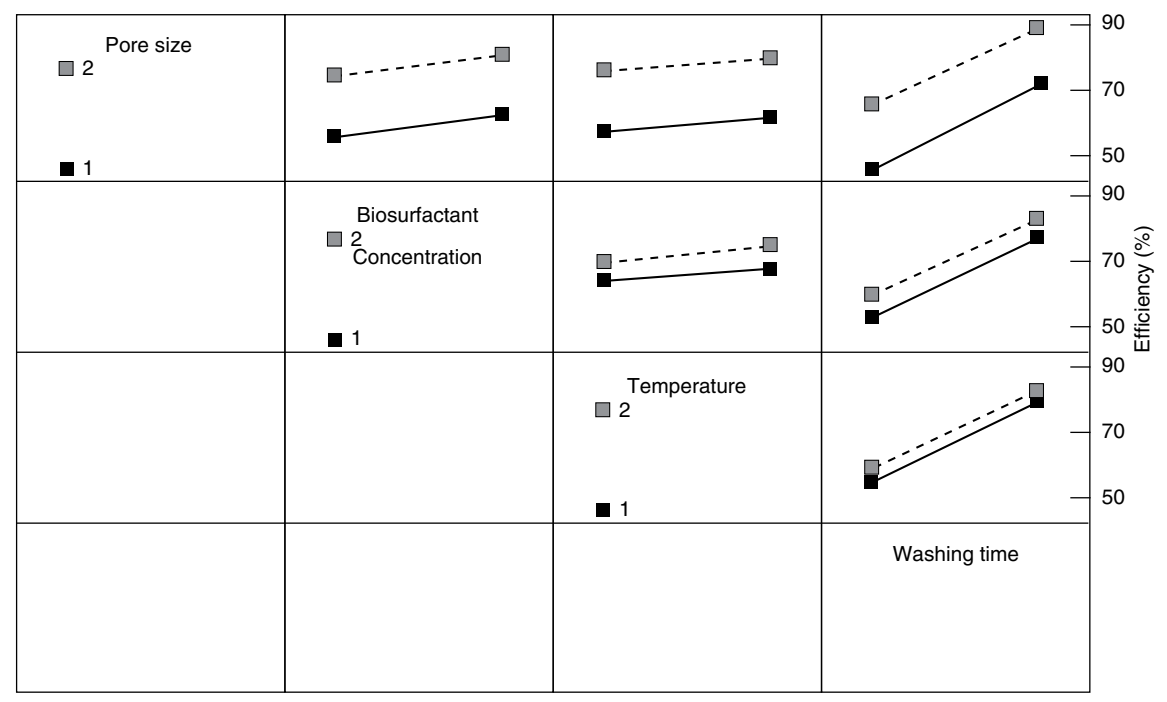

Figure 2

Interaction effects plot: (a) crude oil; (b) 25\% weathered oil; (c) $50 \%$ weathered oil. 


\section{REFERENCES}

Azemar, N., Carrera, I. and Solans, C. (1993) Studies on textile detergency at low temperature. J. Disper. Sci.Technol., 14, 645-660.

Dyke, M.V., Lee, H. and Trevors, J.T. (1991) Applications of microbial surfactants. Biotechnol. Adv., 9, 241-252.

Fu, H. and Matthews, M.A. (1999) Comparison between supercritical carbon dioxide extraction and aqueous surfactant washing of an oily machining waste. J. Hazard.Mater., 67, 197-213.

Peaslee, K.D. and Roberts, D.E. (1997) Characterization of used automotive oil filters for recycling. Resour. Conserv. Recy., 19, 81-91.

Ron, E.Z. and Rosenberg, E. (2002) Biosurfactants and oil bioremediation. Curr. Opin. Biotech., 13, 249-252.
Teas C., Kalligeros, S., Zanikos, F., Stournas, S., Lois, E. and Anastopoulos, G. (2001) Investigation of the effectiveness of absorbent materials in oil spills clean up. Desalination, 140, 259-264.

Wei, Q.F., Mather, R.R., Fotheringham, A.F. and Yang, Y.D. (2003) Evaluation of nonwoven polypropylene oil sorbents in marine oil-spill recovery. Mar. Pollut. Bull., 46, 780-783.

Winer, B.J., Brown, D.R. and Michels, K.M. (1991) Statistical Principles in Experimental Design, McGraw-Hill, Inc.

Wiens J.A. (1996) Oil, seabirds, and science-the effects of the Exxon Valdez oil spill. Bioscience, 46, 587-597.

Yang, R., Mather, R.R. and Fotheringham, A.F. (2001) The application of factorial experimental design to the processing of polypropylene fibres. J. Mater. Sci., 36, 3097-3101.

Final manuscript received in October 2006 